\title{
PENGUJIAN EFIKASI FORMULASI KERING Trichoderma spp. TERHADAP PENYAKIT BUSUK BUAH KAKAO (Phytophthora palmivora)
}

\author{
Ahmad Teddy Wijaya P \& Titik Nur Aeny \\ Jurusan Agroteknologi, Fakultas Pertanian, Universitas Lampung \\ J1. Soemantri Brodjonegoro No. 1 Bandar Lampung 35145 \\ E-mail:
}

\begin{abstract}
ABSTRAK
Penelitian ini bertujuan untuk membuat formulasi keringTrichoderma spp. dengan bahan pembawa yang berbeda-beda (talk, kaolin, dan clay) dan mendapatkan formulasi kering yang paling efektif dalam menekan penyakit busuk buah kakao (BBK) yang disebabkan oleh Phytophthora palmivora. Penyiapan formulasi kering Trichoderma spp. dilakukan di laboratorium dan formulasi kering yang dihasilkan selanjutnya diuji keefektifannya pada buah kakao di laboratorium dan di lapang. Pengujian laboratorium dilakukan di Laboratorium Penyakit Tumbuhan Fakultas Pertanian Universitas Lampung dan pengujian lapang dilakukan di kebun kakao petani di Dusun Sidomulyo Kecamatan Sumberejo, Kabupaten Tanggamus. Formulasi keringTrichoderma diaplikasikan dengan cara penyemprotan pada buah kako, dan semua buah yang diberi perlakuan diinokulasi dengan cara menempelkan potongan biakan $P$. palmivora pada 2 hari setelah perlakuan. Hasil penelitian menunjukkan bahwa Trichoderma spp. dalam bentuk formulasi kering dapat menekan pertumbuhan jamur P. palmivora. Formulasi kering T.harzianum dan T.viride dengan bahan pembawa kaolin memiliki jumlah spora yang paling tinggi. Hasil percobaan di laboratorium menunjukkan bahwa pada 8 hari setelah inokulasi, formulasi kering T.harzianum dengan bahan pembawa kaolin adalah yang paling baik dalam menekan keparahan penyakit(34\%), sedangkan di lapang formulasi T.viridae dengan bahan pembawa kaolin yang paling efektif dalam menekan keparahan penyakit BBK $(26 \%)$.
\end{abstract}

Kata kunci: formulasi kering, penyakit busuk buah kakao, Trichoderma spp.

\section{PENDAHULUAN}

Kakao merupakan salah satu komoditas ekspor yang menempati peringkat ke tiga ekspor sektor perkebunan dalam menyumbang devisa negara, setelah komoditas karet dan CPO. Provinsi Lampung merupakan salah satu sentra perkebunan kakao di Indonesia, dengan lokasi antara lain di Kabupaten Lampung Selatan, Pesawaran, Tanggamus, Lampung Timur, Lampung Tengah, Lampung Utara, Lampung Barat, Pringsewu, dan Waykanan (Bappebti, 2011). Menurut Dirjen Perkebunan (2009) luas areal tanaman kakao di Lampung mencapai 38.865 ha, dengan produksi sebanyak 17.000 ton $(2,9 \%)$.

Sampai saat ini, usaha pengembangan kakao di Indonesia masih menghadapi banyak kendala, salah satunya adalah adanya serangan hama dan penyakit (Darmono et al., 2006). Busuk buah kakao merupakan penyakit utama tanaman kakao yang ditemukan di banyak negara penghasil buah kakao, termasuk Indonesia (Suara Merdeka, 2004). Penyakit yang disebabkan oleh jamur Phytophthora palmivora (Butl.) merupakan penyakit kakao paling penting karena menyebabkan kerugian mencapai 10 - 30\% di seluruh dunia.
Pada saat ini upaya pengendalian terhadap hama dan penyakit tanaman masih mengutamakan penggunaan pestisida sebagai upaya pengendalian utama. Pada kenyataannya bahwa upaya pengendalian dengan menggunakan senyawa kimia bukan merupakan alternatif yang terbaik, karena banyak menimbulkan dampak negatif. Selain itu dengan adanya aplikasi pestisida sintetik yang berlebihan dapat memicu timbulnya patogen yang resisten terhadap pestisida sistetik yang digunakan. Berdasarkan hal tersebut maka perlu diambil alternatif pengendalian yang efektif terhadap penyebab penyakit tanaman tanpa mengandalkan fungisida sistetik. Pengendalian biologi (hayati) menunjukkan alternatif pengedalian yang dapat dilakukan tanpa harus memberikan pengaruh negatif terhadap lingkungan dan sekitarnya, salah satunya adalah dengan pemanfaatan agens hayati seperti virus, jamur atau cendawan, bakteri atau aktiomisetes.

Beberapa jamur atau cendawan mempunyai potensi sebagai agens hayati dari jamur patogenik diantaranya adalah Trichoderma spp. (Baker dan Cook,1983 dalam Tindaon, 2008), yang bersifat antagonis terhadap jamur $P$. palmivora penyebab penyakit busuk buah kakao. Oleh karena itu penggunaan Trichoderma spp. sebagai agen pengendali hayati diharapkan dapat 
mengurangi ketergantungan dan dampak negatif dari penggunaan bahan kimia dalam mengendalikan penyakit busuk buah kakao.

Penelitian ini bertujuan untuk membuat formulasi kering Trichoderma spp. dengan bahan pembawa yang berbeda, dan mendapatkan formulasi kering yang paling efektif dalam menekan penyakit busuk buah kakao.

\section{METODE PENELITIAN}

Percobaan untuk pengujian formulasi kering jamur Trichoderma spp. disusun dalam Rancangan Acak Lengkap yang terdiri dari 10 perlakuan, yaitu 9 formulasi kering dengan komposisi yang berbeda dan 1 kontrol. Masing-masing perlakuan diulang sebanyak 3 kali sehingga terdapat 30 satuan percobaan. Satu percobaan terdiri atas 3 buah kakao. Perlakuan terdiri atas:

1. Kontrol berupa buah kakao yang disemprot dengan air steril (T0C0);

2. Formulasi kering T. harzianum dengan bahan pembawa talk (T1C1);

3. Formulasi kering T. harzianum dengan bahan pembawa kaolin (T1C2);

4. Formulasi kering T. harzianum dengan bahan pembawa clay (T1C3);

5. Formulasi kering T. koningii dengan bahan pembawa talk (T2C1);

6. Formulasi kering T. koningii dengan bahan pembawa kaolin (T2C2);

7. Formulasi kering T. koningii dengan bahan pembawa clay (T2C3);

8. Formulasi kering T. viridee dengan bahan pembawa talk (T3C1);

9. Formulasi kering T. viridee dengan bahan pembawa kaolin (T3C2);

10. Formulasi kering T. viridee dengan bahan pembawa clay (T3C3);

Isolasi dan pemurnian isolat $P$. palmivora pada tahapan ini mengadopsi langkah-langkah yang telah dilakukan oleh Umayah et al., (2006) yaitu jamur patogen diisolasi secara langsung dari buah yang menunjukkan gejala busuk buah. Pada buah yang menunjukkan gejala, dibuat potongan jaringan kulit buah pada perbatasan antara yang sakit dan yang sehat $( \pm 5$ $\mathrm{mm}$ ), lalu potongan-potongan tersebut direndam dalam larutan $\mathrm{NaOCl} 1 \%$ selama 5 menit, kemudian direndam dalam larutan alkohol $70 \%$ selama 2 menit, dan dibilas dengan aquades sebanyak 2 kali. Kemudian potongan buah tersebut ditanam pada cawan petri yang berisi media V8 dan diinkubasi dalam suhu ruang selama 4 hari atau sampai tumbuh koloni. Jamur yang tumbuh pada V8 selanjutnya dibiakkan, dimurnikan, dan diperbanyak pada medium yang sama sampai diperoleh biakan murni dalam jumlah yang cukup banyak.

Trichoderma yang digunakan pada percobaan ini terdiri atas tiga spesies yaitu $T$. viride, T. koningii, dan T. harziaum. Biakan Trichoderma yang sudah murni diperbanyak dalam media perbanyakan berupa menir beras dan diinkubasi dalam inkubator selama 30 hari untuk mendapatkan spora/konidia dalam jumlah yang cukup banyak. Perbanyakan biakan untuk starter (pemula) dilakukan sebagai berikut: sebanyak 100 gr menir yang telah dikukus setengah matang dimasukkan ke dalam 10 plastik tahan panas kemudian diikat sampai kedap udara yang lalu disterilkan dalam autoklaf pada suhu $121^{\circ} \mathrm{C}$ (tekanan $1 \mathrm{~atm}$ ) selama kurang lebih 30 menit. Media menir yang telah disterilkan dibiarkan dingin lalu diinokulasi dengan jamur Trichoderma spp. dan diinkubasi selama 2-3 minggu atau sampai terbentuk spora secara merata pada media menirnya.

Biakan hasil perbanyakan jamur Trichoderma spp. dalam menir beras dikeringanginkan pada suhu 30$35^{\circ} \mathrm{C}$ sampai benar-benar kering, kemudian diblender dan disaring untuk memisahkan spora dari ampasnya. Pada tahap berikutnya (tahap pencampuran) spora yang telah halus dicampurkan ke bahan pembawa (carrier) yang berbeda yaitu talk, kaolin, dan clay untuk mendapatkan sembilan formulasi yang merupakan kombinasi antara tiga spesies Trichoderma dengan tiga macam bahan pembawa. Kesembilan formulasi kering tersebut yang kemudian digunakan dalam pengujian antagonisme terhadap $P$. palmivora.

Pengujian formulasi kering jamur Trichoderma spp (T.harzianum, T.koningii, dan T.viride) dilakukan pada buah kakao di dalam laboratorium dan pada buah kakao di lapang. Dosis yang digunakan yaitu $2 \mathrm{~g} \mathrm{l}^{-1}$ (mengacu pada rekomendasi pada label Natural BVR). Pada percobaan di laboratorium sebanyak 30 buah kakao yang sehat dan segar dipetik dari lapang, Aplikasi perlakuan dilakukan dengan cara menyemprotkan suspensi formulasi kering Trichoderma secara merata ke permukaan buah kakao. Setelah 3 hari, buah kakao diinokulasi dengan cara menempelkan potongan cakram $(\varnothing 0,8 \mathrm{~cm})$ biakan jamur P. palmivora berumur 14 hari pada bagian tengah permukaan buah kakao. Pengamatan dilakukan setiap hari sampai gejala penyakit muncul dan dilanjutkan sampai gejala terebut memenuhi buah kakao pada kontrol. Percobaan pada skala lapang, secara teknis pelaksanaannya sama dengan yang dilakukan di laboratorium. Hal yang membedakan adalah pada skala lapang buah kakao tetap dibiarkan di pohon.

Pengamatan dilakukan setiap hari terhadap munculnya gejala pertama dan pengamatan selanjutnya dilakukan untuk mengukur perkembangan diameter 
gejala penyakit busuk buah kakao yang muncul. Pengukuran gejala pada buah dilakukan masing-masing sebanyak dua kali pada diameter vertikal dan horizontal buah kemudian dirata-ratakan. Selanjutnya, intensitas penyakit dihitung berdasarkan diseased area yaitu persentase perbandingan antara luas bagian buah yang sakit (bergejala) dengan luasan total permukaan buah.

\section{HASIL DAN PEMBAHASAN}

Hasil pengamatan di laboratorium menunjukkan bahwa buah kakao yang dipetik dari lapang dan dibawa ke laboratorium untuk diiinokulasi secara buatan dengan inokulum jamur $P$. palmivora menghasilkan kemunculan gejala awal dan perkembangan gejala yang bervariasi satu sama lain (Tabel 1). Perkembangan gejala BBK yang berupa perubahan warna di sekitar potongan biakan jamur patogen juga mempunyai kecepatan yang berbedabeda (ditunjukkan oleh masa inkubasi yang berbedabeda). Keparahan penyakit BBK pada masing-masing perlakuan dapat dilihat pada Tabel 2. Pada Tabel 2 terlihat bahwa secara umum perlakuan semua formulasi Trichoderma secara nyata dapat menghambat keparahan penyakit BBK yang muncul. Pada hari pengamatan yang terakhir yaitu $8 \mathrm{HSI}$, buah pada kontrol sudah menunjukkan keparahan penyakit hampir seratus persen $(99,33 \%)$ sedangkan buah yang diberi perlakuan $T$. harzianum dengan jenis bahan pembawa apapun (T1C2, T1C2, dan T1C3) mempunyai keparahan yang lebih rendah dari kontrol. Selain itu, formulasi kering

Tabel 1. Masa inkubasi penyakit bubuk buah kakao di laboratorium

\begin{tabular}{cc}
\hline Perlakuan & Masa inkubasi (hari) \\
\hline Kontrol & $2,00 \mathrm{e}$ \\
T1C1 & $3,33 \mathrm{abcde}$ \\
T1C2 $2,00 \mathrm{a}$ \\
T1C3 & $4,00 \mathrm{abc}$ \\
T2C1 & $4,33 \mathrm{ab}$ \\
T2C2 & $3,33 \mathrm{abcde}$ \\
T2C3 & $4,00 \mathrm{abc}$ \\
T3C1 & $4,00 \mathrm{abc}$ \\
T3C2 & $2,00 \mathrm{e}$ \\
T3C3 & $3,33 \mathrm{e}$ \\
\hline
\end{tabular}

Keterangan: Nilai dalam kolom yang diikuti huruf yang sama, tidak berbeda nyata menurut uji BNT $\alpha=0,05$. $(\mathrm{T} 1=T$. harzianum $; \mathrm{T} 2=T$. koningii $; \mathrm{T} 3=T$. viride $; \mathrm{C} 1=$ talk $; \mathrm{C} 2=$ kaolin $; \mathrm{C} 3=$ tanah liat $)$

Tabel 2. Keparahan penyakit busuk buah kakao di laboratorium

\begin{tabular}{cccccc}
\hline \multirow{2}{*}{ Perlakuan } & \multicolumn{5}{c}{ Luas area gejala penyakit busuk buah kakao (\%) pada } \\
\cline { 2 - 6 } & $2 \mathrm{Hsi}$ & $3 \mathrm{Hsi}$ & $4 \mathrm{Hsi}$ & $7 \mathrm{Hsi}$ & $8 \mathrm{Hsi}$ \\
\hline Kontrol & $25,67 \mathrm{a}$ & $36,67 \mathrm{a}$ & $50,00 \mathrm{a}$ & $94,33 \mathrm{a}$ & $99,33 \mathrm{a}$ \\
T1C1 & $0,00 \mathrm{c}$ & $3,33 \mathrm{~b}$ & $12,33 \mathrm{~b}$ & $56,33 \mathrm{c}$ & $62,67 \mathrm{~b}$ \\
T1C2 & $1,67 \mathrm{c}$ & $7,33 \mathrm{~b}$ & $14,67 \mathrm{~b}$ & $26,67 \mathrm{bc}$ & $34,00 \mathrm{c}$ \\
T1C3 & $2,00 \mathrm{c}$ & $16,00 \mathrm{~b}$ & $36,67 \mathrm{ab}$ & $50,00 \mathrm{bc}$ & $60,00 \mathrm{~b}$ \\
T2C1 & $8,33 \mathrm{~b}$ & $15,00 \mathrm{~b}$ & $21,67 \mathrm{~b}$ & $55,00 \mathrm{bc}$ & $68,33 \mathrm{ab}$ \\
T2C2 & $3,33 \mathrm{bc}$ & $11,00 \mathrm{~b}$ & $24,00 \mathrm{~b}$ & $60,00 \mathrm{bc}$ & $68,33 \mathrm{ab}$ \\
T2C3 & $0,00 \mathrm{c}$ & $14,00 \mathrm{~b}$ & $20,67 \mathrm{~b}$ & $65,00 \mathrm{bc}$ & $71,67 \mathrm{ab}$ \\
T3C1 & $2,67 \mathrm{bc}$ & $8,67 \mathrm{~b}$ & $18,33 \mathrm{~b}$ & $48,33 \mathrm{bc}$ & $58,67 \mathrm{~b}$ \\
T3C2 & $6,00 \mathrm{bc}$ & $9,00 \mathrm{~b}$ & $17,33 \mathrm{~b}$ & $71,67 \mathrm{ab}$ & $71,00 \mathrm{ab}$ \\
T3C3 & $3,33 \mathrm{bc}$ & $5,67 \mathrm{~b}$ & $23,33 \mathrm{~b}$ & $50,67 \mathrm{bc}$ & $53,33 \mathrm{~b}$ \\
\hline BNT & 5.69 & 13.92 & 24.57 & 26.39 & 31.23 \\
\hline
\end{tabular}

Keterangan : Nilai dalam kolom yang diikuti huruf yang sama, tidak berbeda nyata menurut uji BNT $\alpha=0,05$. 
T.viride dengan bahan pembawa talk dan clay juga menunjukkan hasil yang sama.

Pengujian formulasi kering Trichoderma spp. di lapang pada prinsipnya mengunakan metode yang sama pada pengujian di laboratorium, yang membedakan adalah jika pada pengujian di lapang, buah kakao tetap dibiarkan di pohon. Pada pengamatan di lapang, setiap perlakuan memiliki perbedaan pada masa inkubasi, dimana tiap perlakuan memiliki masa inkubasi yang berbeda antara satu sama lain (Tabel 3). Selanjutnya dilakukan pengukuran tingkat keparahan penyakit yang dapat dilihat pada Tabel 4. Dari tabel tersebut dapat terlihat bahwa perlakuan tanpa aplikasi formulasi kering Trichoderma (kontrol) memiliki rata-rata persentase pertumbuhan gejala penyakit yang lebih besar dibandingkan buah kakao yang mendapatkan perlakuan. Dari data tersebut juga dapat terlihat bahwa antara satu perlakuan dengan perlakuan lainnya tidak selalu berbeda nyata dengan kontrol.

Dari Tabel 1 dapat diketahui bahwa formulasi T2C1 (T. koningii dengan bahan pembawa talk) mempunyai masa inkubasi terlama dengan rata-rata 4,33 hari, sedangkan kontrol dan T3C2 (T. viride dengan bahan pembawa kaolin) mempunyai masa inkubasi paling cepat $(0,66$ hari). Hal ini mengindikasikan bahwa formulasi $T$. koningii dengan bahan pembawa talk mempunyai kemampuan menghambat perkembangan penyakit BBK yang lebih baik dibandingkan dengan perlakuan lainnya. Dari hasil pengujian di laboratorium pada 8HSI tampak bahwa perlakuan berupa formulasi

Tabel 3. Masa inkubasi penyakit busuk buah kakao di lapangan

\begin{tabular}{cc}
\hline Perlakuan & Masa inkubasi (hari) \\
\hline Kontrol & $2,00 \mathrm{e}$ \\
T1C1 & $9,33 \mathrm{ab}$ \\
T1C2 & $9,67 \mathrm{a}$ \\
T1C3 & $6,67 \mathrm{abc}$ \\
T2C1 & $6,00 \mathrm{abcde}$ \\
T2C2 & $2,00 \mathrm{e}$ \\
T2C3 & $2,00 \mathrm{e}$ \\
T3C1 & $2,67 \mathrm{de}$ \\
T3C2 & $6,33 \mathrm{abcd}$ \\
T3C3 & $5,00 \mathrm{cde}$ \\
\hline
\end{tabular}

Keterangan: Nilai dalam kolom yang diikuti huruf yang sama, tidak berbeda nyata menurut uji BNT $\alpha=0,05$. $(\mathrm{T} 1=T$. harzianum $; \mathrm{T} 2=T$. koningii $; \mathrm{T} 3=T$. viride $; \mathrm{C} 1=$ talk $; \mathrm{C} 2=$ kaolin $; \mathrm{C} 3=$ tanah liat $)$.

Tabel 4. Persentase luasan gejala penyakit busuk buah kakao di lapang

\begin{tabular}{ccccccl}
\hline \multirow{2}{*}{ Perlakuan } & \multicolumn{5}{c}{ Luas area gejala penyakit busuk buah kakao (\%) pada } \\
\cline { 2 - 7 } & $3 \mathrm{Hsi}$ & $5 \mathrm{Hsi}$ & $7 \mathrm{Hsi}$ & $9 \mathrm{Hsi}$ & $11 \mathrm{Hsi}$ & $13 \mathrm{Hsi}$ \\
\hline Kontrol & $17,33 \mathrm{a}$ & $26,00 \mathrm{a}$ & $27,67 \mathrm{a}$ & $52,33 \mathrm{a}$ & $88,33 \mathrm{a}$ & $95,00 \mathrm{a}$ \\
T1C1 & $1,67 \mathrm{~d}$ & $4,33 \mathrm{~d}$ & $5,00 \mathrm{e}$ & $8,33 \mathrm{e}$ & $18,33 \mathrm{f}$ & $40,00 \mathrm{de}$ \\
T1C2 & $1,00 \mathrm{~d}$ & $4,00 \mathrm{~d}$ & $5,00 \mathrm{e}$ & $10,00 \mathrm{e}$ & $18,33 \mathrm{f}$ & $33,33 \mathrm{e}$ \\
T1C3 & $1,00 \mathrm{~d}$ & $4,33 \mathrm{~d}$ & $7,33 \mathrm{e}$ & $18,00 \mathrm{cde}$ & $53,33 \mathrm{bcd}$ & $87,00 \mathrm{ab}$ \\
T2C1 & $2,67 \mathrm{~d}$ & $6,67 \mathrm{~d}$ & $15,33 \mathrm{de}$ & $28,00 \mathrm{~cd}$ & $46,67 \mathrm{bcde}$ & $63,33 \mathrm{abcde}$ \\
T2C2 & $7,67 \mathrm{bc}$ & $15,00 \mathrm{bcd}$ & $18,67 \mathrm{abcd}$ & $27,00 \mathrm{cde}$ & $45,00 \mathrm{bcdef}$ & $66,00 \mathrm{abcd}$ \\
T2C3 & $8,67 \mathrm{~b}$ & $18,67 \mathrm{~b}$ & $25,00 \mathrm{ab}$ & $46,67 \mathrm{ab}$ & $63,33 \mathrm{ab}$ & $95,00 \mathrm{a}$ \\
T3C1 & $4,67 \mathrm{~cd}$ & $16,67 \mathrm{bc}$ & $20,33 \mathrm{abc}$ & $28,33 \mathrm{c}$ & $55,00 \mathrm{bc}$ & $78,33 \mathrm{abc}$ \\
T3C2 & $3,33 \mathrm{~d}$ & $9,33 \mathrm{~d}$ & $11,00 \mathrm{de}$ & $14,33 \mathrm{cde}$ & $33,33 \mathrm{cdef}$ & $26,67 \mathrm{e}$ \\
T3C3 & $3,67 \mathrm{~cd}$ & $9,00 \mathrm{~d}$ & $11,00 \mathrm{de}$ & $20,00 \mathrm{cde}$ & $33,33 \mathrm{cdef}$ & $39,00 \mathrm{e}$ \\
\hline BNT & 3,79 & 7,18 & 9,14 & 16,95 & 25,91 & 34,77 \\
\hline
\end{tabular}

Keterangan : Nilai dalam kolom yang diikuti huruf yang sama, tidak berbeda nyata menurut uji BNT $\alpha=0,05$. 
kering T.harzianum dengan bahan pembawa kaolin (T1C2) menunjukkan hasil yang paling baik yaitu keparahannya paling rendah (34\%). Hasil ini sejalan dengan laporan Sankar \& Jeyarajan (1996) bahwa penambahan kaolin dalam formulasi Trichoderma dapat membuatnya bertahan $3-4$ bulan.

Pada percobaan di lapang, rata-rata masa inkubasi penyakit BBK lebih singkat dibandingkan pada percobaan di laboratorium. Hal ini diduga disebabkan oleh beberapa faktor lingkungan yaitu suhu dan kelembaban, serta keberadaan inokulum patogen P.palmivora di lapang. Pada percobaan di lapang ini, formulasi dengan perlakuan T1C3 (T. harzianum dengan bahan pembawa tanah liat) mempunyai ratarata masa inkubasi paling lama, yaitu 6,67 hari. Pada perlakuan $T$. harzianum dengan bahan pembawa talk (T1C1), T. harzianum dengan bahan pembawa kaolin (T1C2), T. viride dengan bahan pembawa kaolin (T3C2), dan T. viride dengan bahan pembawa tanah liat (T3C3) efektif menghambat pertumbuhan jamur $P$. palmivora pada buah kakao, hal ini terlihat dari kecilnya diameter gejala penyakit busuk buah sampai dengan hari ke-13 setelah inokulasi. Maka dapat dikatakan bahwa ketiga perlakuan tersebut adalah yang paling baik dalam menghambat perkembangan jamur patogen dilapang.

Data yang didapat secara keseluruhan juga menunjukkan bahwa seluruh perlakuan kecuali perlakuan T. koningii dengan bahan pembawa tanah liat (T2C3), memiliki kemampuan menghambat perkembangan penyakit busuk buah, walaupun dalam persentase yang berbeda antar perlakuan. Pada perlakuan yang mengandung T.koningii (T2) terlihat kemampuan penghambatan tidak maksimal, bahkan pada perlakuan T2C3 sama sekali tidak menghambat. Pada perlakuan T2C3, selain karena faktor T.koningii yang diduga tidak maksimal, juga diduga disebabkan adanya faktor bahan pencampur yaitu Clay (C3). Hal ini dapat terlihat bahwa 2 dari 3 perlakuan yang menggunakan bahan pencampur C3, hasilnya kurang maksimal dalam penghambatan penyakit busuk buah kakao. Clay dilaporkan kurang memberikan efek yang positif terhadap formulasi Trichoderma. Sankar \& Jeyarajan (1996) melaporkan bahwa bahan tambahan berupa talk dan kaolin pada formulasi Trichoderma dapat bertahan selama 3 - 4 bulan, tetapi viabilitas Trichoderma dalam talk akan menurun 50\% setelah masa penyimpanan selama 120 hari.

\section{KESIMPULAN}

Formulasi kering T.harzianum dan T.viride dengan bahan pembawa kaolin memiliki jumlah spora yang paling tinggi. Hasil percobaan di laboratorium menunjukkan bahwa pada 8 hari setelah inokulasi, formulasi kering T.harzianum dengan bahan pembawa kaolin paling baik dalam menekan keparahan penyakit(34\%), Hasil percobaan di lapang menunjukkan bahwa formulasi T.viridae dengan bahan pembawa kaolin paling efektif dalam menekan keparahan penyakit BBK (26\%).

\section{DAFTAR PUSTAKA}

Bappebti. 2011. Analisis Perkembangan Harga; Harga Kakao Kembali Turun. Badan Pengawas Perdagangan Berjangka Komoditi. Kementrian Perdagangan Republik Indonesia.

Bhattacharyya, S. K. \& Basu, M, K. 1982. Kaolin Powder as a Fungal Carrier. Applied and Environment Microbiology. 44 (3) : 751-753 pp.

Darmono, T.W., Jamil, I. \& Santosa, D.A. 2006 ${ }^{\text {b }}$ Pengembangan Penanda Molekuler Untuk Deteksi Phytophthora palmivora pada Tanaman Kakao.

Sankar, P. J. R. 1996. Biological control of sesamum root rot by seed treatment with Trichoderma spp. and Bacillus subtilis. Indian Journal of Mycology and Plant Pathology 26: 147-53.

Tindaon, H., 2008. Pengaruh Jamur Antagonis Trichoderma harzianum danPupuk Organik Untuk Mengendalikan Patogen Tular Tanah Sclerotium roflsii Sacc. Pada Tanaman Kedelai (Glycine max L.) di Rumah Kasa. http:/ /repository.usu.ac.id.pdf Akses 10 Februari 2013 